\title{
Significance of free-floating macrophytes in the ecology of a sandy beach surf zone
}

\author{
Deon van der Merwe \& Anton McLachlan
}

Zoology Department, University of Port Elizabeth, PO Box 1600, Port Elizabeth 6000, South Africa

\begin{abstract}
Macrophytes, detached by storms and heavy wave action, accumulate in the surf zone off King's Beach, Algoa Bay, South Africa. The composition of these macrophytes, their temporal and spatial occurrence, and their associated fauna were investigated. These macrophytes are a transient feature at King's Beach. They are living and actively photosynthesizing while in the surf zone, thus breaking down very slowly. Mesh bags containing the 2 dominant species of red algae were placed behind the breakers and breakdown rates of the algae monitored. In addition, changes in faunal biomass values and numbers were analysed. In bags with $10 \mathrm{~mm}$ mesh, $50 \%$ breakdown occurred after $8 \mathrm{~d}$ and in bags with $2 \mathrm{~mm}$ mesh, after $26 \mathrm{~d}$. These algae pass through the beach system rapidly in longshore currents and do not accumulate there. They are neither important in the energetics of the surf zone nor form an important nursery area for juvenile fishes at King's Beach. The fauna associated with these algae is derived from their attachment sites of origin and does not colonize them in the surf. Amphipods dominate the epifauna.
\end{abstract}

\section{INTRODUCTION}

The role of beached macrophytes in coastal food web dynamics has been investigated by several authors (e.g. Griffiths \& Stenton-Dozey 1981, Koop \& Field 1981). The influence of surf zone accumulations of plants on ecological processes in coastal marine environments has, however, received less attention (Lenanton et al. 1982), particularly in terms of macrofaunal-drift algae associates (Kulczycki et al. 1981).

Along the western Australian coast large numbers of macrophytes are removed from nearshore seagrass meadows and kelp beds by storms and heavy swells. These macrophytes accumulate along the shore forming large patches of plant material in the surf zone and wrack banks on beaches and rocks (Lenanton et al. 1982). Similar wrack accumulations were recorded by Zobell (1971). According to Lenanton et al. (1982) a number of fish species use portions of the open coast of south-western Australia as an alternative to estuaries as nursery areas. The detached macrophyte accumulations provide a source of food and shelter for these fishes (Lenanton et al. 1982) and also a habitat for epifauna (Eiseman \& Benz 1975, Hooks et al. 1976, Cowper 1978, Heck 1979, Gore et al. 1981, Heck \& Thoman 1981, Kulczycki et al. 1981).

The aim of this study was to evaluate the role of detached macrophytes in a Southern African surf zone by determining whether these algal accumulations are important in surf zone energetics and/or are utilised as nursery areas for juvenile fishes, as recorded elsewhere.

\section{MATERIALS AND METHODS}

Study area. King's Beach $\left(33^{\circ} 58^{\prime} \mathrm{S}, 25^{\circ} 39^{\prime} \mathrm{E}\right)$, is an ENE-facing beach, stretching $1.3 \mathrm{~km}$ in a southerly direction from the harbour of Port Elizabeth (Fig. 1).

This is a medium energy beach, being less exposed than other beaches in Algoa Bay, as it is protected from the prevailing south-westerly winds by the mainland of Cape Recife (Lasiak 1984). King's Beach experiences continuous moderate wave action; waves break at a distance of 50 to $100 \mathrm{~m}$ offshore and have an average breaking height of $0.7 \mathrm{~m}$ (McLachlan 1980). The physical, chemical and biological features of King's Beach have been described by McLachlan $(1977,1979,1980)$. The temperate waters of Algoa Bay are subjected to seasonal fluctuations with a maximum temperature range of 11 to $26^{\circ} \mathrm{C}$ in the surf (Lasiak 1984). However, temperature varied between 14 and $18^{\circ} \mathrm{C}$ during this study. Tides are semidiurnal subequal with a maximum spring range of $2.1 \mathrm{~m}$.

Field sampling. Algal wrack is most abundant in the 


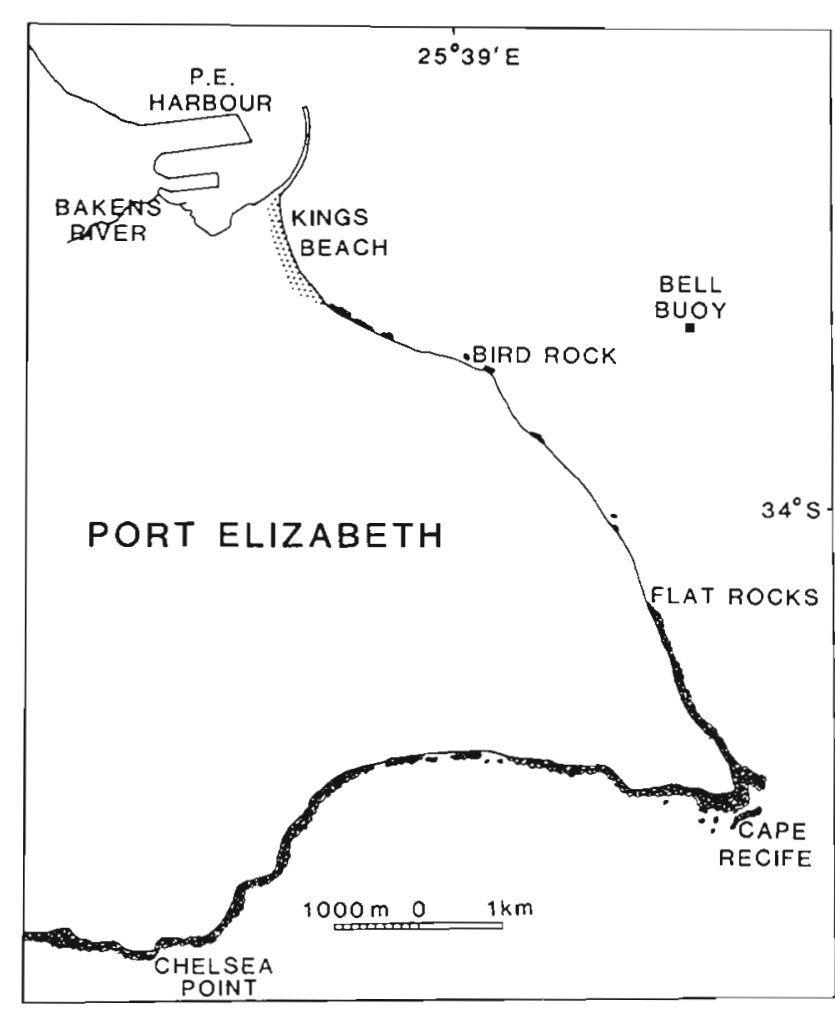

Fig. 1. Map of Cape Recife peninsula study area, South Africa

surf during late summer. A total of 16 hauls were made during February and March 1984 with a beach seine net (10 mm stretched mesh), $4 \mathrm{~m}$ long and $2 \mathrm{~m}$ deep. All algae and animals were placed in plastic bags. Additional information was obtained from hauls made with a $30 \mathrm{~m}$ long, $2 \mathrm{~m}$ deep purse-seine net $(17 \mathrm{~mm}$ stretched mesh) with a $2 \mathrm{~m}$ deep purse-bag at its mid-point. These hauls were made at twilight and in the dark once a month, from April to July 1984, and several times early in 1985.

During the period February to August 1984, King's Beach was visited on 32 occasions at approximately $1700 \mathrm{~h}$ each time. The amount of macrophytes in the surf was determined by snorkeling in the surf or by wading and was rated on a scale from 0 to 10 .

Hourly observations of wind speeds and direction for the months February to August 1984 were obtained from the H. F. Verwoerd airport weather station, $2 \mathrm{~km}$ from the beach. Wind data obtained were correlated with the amount of algae in the surf using a multiple linear regression program.

Laboratory analysis. Plastic bags with collected algae were turned upside down and left for approximately 30 min for most of the water to drain out before total wet weight was determined. One to 4 subsamples (depending on the size of the sample) were taken from the larger samples. All fish from each haul were col- lected and counted; samples were frozen for later analysis.

The composition of the detached macrophytes was determined by sorting the algae of 3 subsamples of approximately $500 \mathrm{~g}$ (wet weight). The algae were then identified and dried at $65^{\circ} \mathrm{C}$ for $3 \mathrm{~d}$ to determine dry mass.

After the subsamples were defrosted, animals were removed. Larger pieces of algae were separated by washing in a glass beaker to remove all animals and smaller pieces of algae. Smaller pieces of algae were then removed from the subsample by sorting in a large flat tray. Small amounts of the very fine algae/animal mixture were placed in a flat glass container and water was slowly added to the mixture, causing the amphipods (the most abundant animals) to be lifted from the algae by the surface tension of the water. Most of the water was decanted through a fine sieve to remove the animals. The procedure was repeated 5 to 6 times. The container with material for examination was placed first on a white and then on a black background, remaining animals were picked out and preserved in a $10 \%$ formalin solution. Later these animals were counted and identified as far as possible. Each taxon was dried separately at $65^{\circ} \mathrm{C}$ for $48 \mathrm{~h}$ and weighed. The dry mass of the separated algae was also determined.

Litter bag experiment. The 2 most abundant species of algae (Laurencia natalensis and Plocamium corallorhiza) observed in the surf at King's Beach were used for this experiment to see whether breakdown was rapid enough to occur in the surf zone. Approximately $4 \mathrm{~kg}$ of each species of algae was removed from the subtidal rocks at Flat Rocks (Fig. 1). The algae were placed in 2 large buckets with seawater which were kept aerated in the laboratory. Approximately $250 \mathrm{~g}$ of each of the 2 species of algae was placed in each of 28 mesh bags. The bags $(23 \times 43 \mathrm{~cm}$, about $500 \mathrm{ml}$ volume) were of 2 mesh sizes, 14 had $2 \mathrm{~mm}$ mesh and 14 had $10 \mathrm{~mm}$ mesh $(2 \mathrm{~mm}$ mesh with holes of $10 \mathrm{~mm}$ punched $20 \mathrm{~mm}$ apart). These bags each contained the 2 species of algae and were tied in groups of 4 $(2 \times 2 \mathrm{~mm}$ mesh and $2 \times 10 \mathrm{~mm}$ mesh) to 7 concrete blocks (Fig. 2).

The period between collecting the algae and placing them in the surf was less than $5 \mathrm{~h}$. The concrete blocks, $40 \times 40 \times 10 \mathrm{~cm}$, were placed in a straight line, $3 \mathrm{~m}$ apart, parallel to the beach, just outside the breakers at King's Beach, $6 \mathrm{~d}$ prior to attaching the bags with algae to them. A connecting rope was installed to prevent the blocks from washing away and to make sampling easier in bad visibility. The blocks were marked with buoys. To enable the bags with algae to move freely, they were each tied to a $1 \mathrm{~m}$ piece of rope.

Two bags of each mesh size were collected at any 
Fig. 2. Diagrammatic representation of the mesh bag experiment conducted in the surf at King's Beach

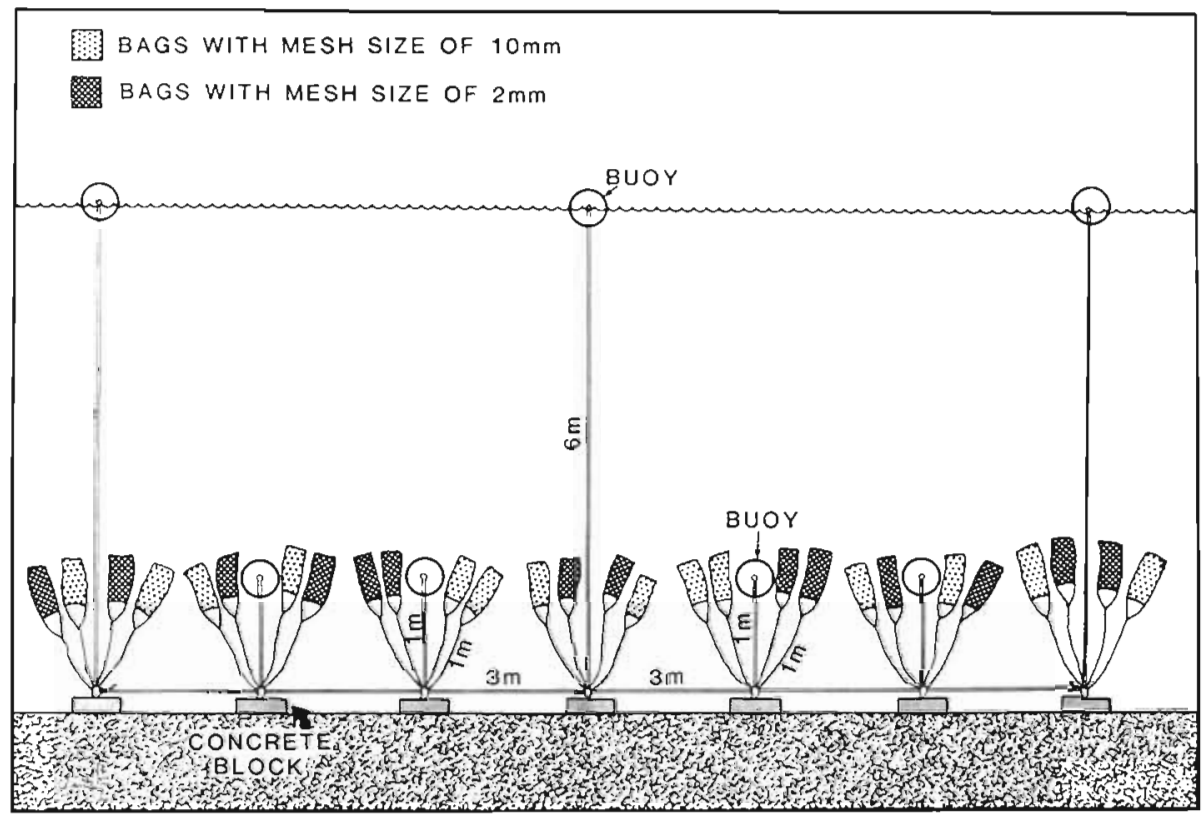

one time by trapping the whole bag in a larger plastic bag and cutting the rope free. At first the bags were removed every $3 \mathrm{~d}$ but as it became apparent that the breakdown rate of the algae was very slow, the collecting times were spaced 12 to $15 \mathrm{~d}$ apart.

Animals were removed from the algae the same way as described above. Numbers were determined and taxa were dried $\left(24 \mathrm{~h}\right.$ at $\left.65^{\circ} \mathrm{C}\right)$ and weighed.

\section{RESULTS}

\section{Algae}

The 3 most important species collected in the King's Beach surf - Plocamium corallorhiza, Laurencia natalensis and Stypopodium zonale - accounted for $44.8 \%$ of the total algal dry mass (Fig. 3).

Of the total dry mass of samples taken, $19 \%$ was made up of non-algae, i.e. man-made refuse, land plants, worm tubes, crustacean exoskeletons, hydroids, bryozoans and other animals. The high percentage of unidentified algae $(14.4 \%)$ was mainly due to various corallines which lose very little weight when dried.

Estimation of the total algal abundance in the surf zone is very difficult due to patchy distribution and irregular occurrence in the surf. This surf zone is $1.3 \mathrm{~km}$ long and averages $70 \mathrm{~m}$ wide. Maximum densities of up to $238 \mathrm{~g}$ (wet weight) algae per cubic meter of seawater were encountered in March, although 22 out of 32 observations showed no algae at all. No significant correlation was found between wind intensity and/or direction and abundance of algae in the surf.

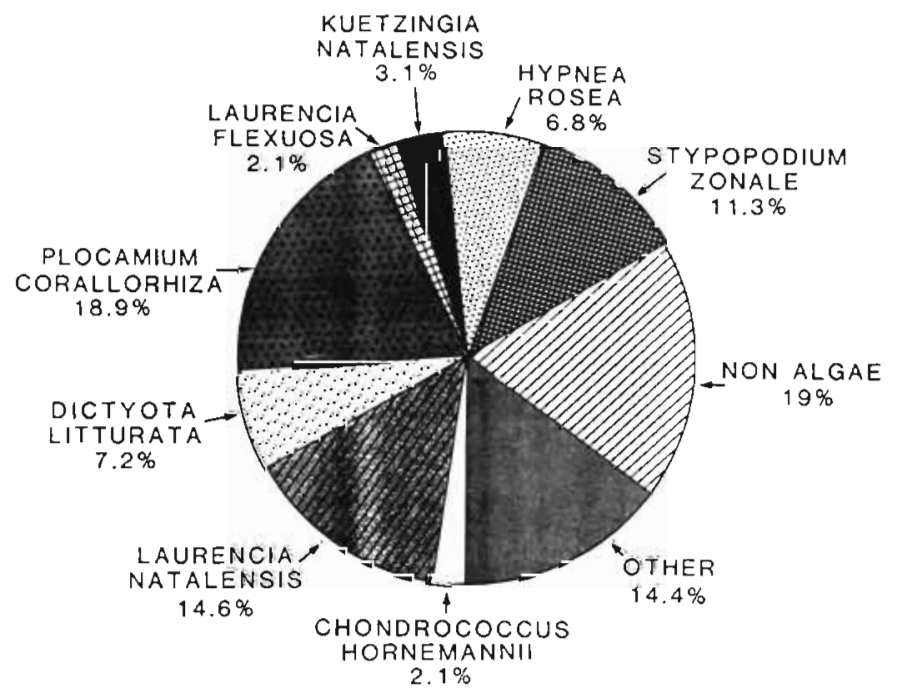

Fig. 3. Percentage composition of algae sampled in the surf zone at King's Beach

\section{Fauna associated with the algae}

Wet weights of algae and numbers of fish netted in the surf are presented in Table 1. A total of 64 fish of 4 species were caught. The blacktail Diplodus sargus made up $73.4 \%$ of the catch by abundance, followed by the gorrie Pomadasys olivaceum (18.8\%). The number of fish caught in the surf showed no significant correlation with the mass of algae netted at the same time $(\mathrm{p}>0.005)$.

No quantitative information was obtained from the 
Table 1. Total wet weight $(\mathrm{g})$ of algae and number of fish caught per net haul

\begin{tabular}{|c|c|c|c|c|c|c|c|}
\hline $\begin{array}{l}\text { Date } \\
(1984)\end{array}$ & Haul no. & Algae wet wt. & $\begin{array}{l}\text { Total no. } \\
\text { of fish }\end{array}$ & $\begin{array}{c}\text { Diplodus } \\
\text { sargus }\end{array}$ & $\begin{array}{l}\text { Pomadasys } \\
\text { olivaceum }\end{array}$ & $\begin{array}{c}\text { Lithognathus } \\
\text { mormyrus }\end{array}$ & $\begin{array}{c}\text { Trachinotus } \\
\text { africanus }\end{array}$ \\
\hline \multirow[t]{5}{*}{24 Feb } & 1 & 2276.3 & 0 & & & & \\
\hline & 2 & 2619.5 & 0 & & & & \\
\hline & 3 & 2688.4 & 0 & & & & \\
\hline & 4 & 2129.4 & 0 & & & & \\
\hline & Mean & 2428.4 & 0 & & & & \\
\hline \multirow[t]{5}{*}{$26 \mathrm{Mar}$} & 1 & 5234.3 & 3 & & 2 & 1 & \\
\hline & 2 & 529 & 7 & 5 & 2 & & \\
\hline & 3 & 1071 & 4 & 2 & 1 & 1 & \\
\hline & 4 & 2309 & 2 & & 2 & & \\
\hline & Mean & 2285.8 & 4 & 1.75 & 1.75 & 0.5 & \\
\hline \multirow[t]{5}{*}{$27 \mathrm{Mar}$} & 1 & 5344 & 0 & & & & \\
\hline & 2 & 12686 & 0 & & & & \\
\hline & 3 & 23836 & 0 & & & & \\
\hline & 4 & 721 & 0 & & & & \\
\hline & Mean & 10647 & 0 & & & & \\
\hline \multirow[t]{5}{*}{$28 \mathrm{Mar}$} & 1 & 0.76 & 0 & & & & \\
\hline & 2 & 0 & 1 & 1 & & & \\
\hline & 3 & 1.22 & 2 & 2 & & & \\
\hline & 4 & 0 & 27 & 25 & & & 2 \\
\hline & Mean & 0.5 & 7.5 & 7 & & & 0.5 \\
\hline \multirow[t]{5}{*}{19 Apr } & 1 & 0 & 0 & & & & \\
\hline & 2 & 0 & 3 & 3 & & & \\
\hline & 3 & 0 & 0 & & & & \\
\hline & 4 & 0 & 15 & 9 & 5 & 1 & \\
\hline & Mean & & 4.5 & 3 & 1.25 & 0.25 & \\
\hline
\end{tabular}

large seine nettings but in most cases very large numbers of juvenile fish and Macropetasma africanum, a surf prawn, were encountered although no algae were netted.

Table 2 contains a list of the fauna encountered in the samples collected in the surf at King's Beach as well as the mean numbers of each taxon per $500 \mathrm{~g}$ of dry algae. The amphipod Paramoera capensis was the dominant species. Numerically, crustaceans accounted for $85.9 \%$ of the fauna found in the algae, and molluscs $10.7 \%$ (Table 3 ). The high crustacean numbers were mainly due to amphipods and the extremely high number of Macropetasma africanum caught on one occasion (26 Mar 1984). Crustaceans dominated biomass (58.8\%) followed by molluscs $(29 \%)$. Polychaetes and echinoderms made up the balance of the fauna. The mean total biomass per $500 \mathrm{~g}$ of algae was $27.03 \mathrm{~g}$

The data in Tables $2 \& 3$ indicate that the prawn Macropetasma africanum was present in the surf zone at all times as confirmed also by additional hauls made with the $30 \mathrm{~m}$ net. The 8 hauls made on 28 March and 19 April 1984 contained no or very little algae ( $2 \mathrm{~g}$ wet weight). However, $M$. africanus was caught in 6 of the 8 hauls made on these dates. Its presence showed no significant correlation with the amount of algae present.

\section{Litter bag experiment}

No significant differences were found between the degradation rates of Plocamium corallorhiza and Laurencia natalensis (Fig. 4). P. corallorhiza had a calculated half-life of $27 \mathrm{~d}$ and L. natalensis of $25 \mathrm{~d}$ in the 2 mm mesh bags, while both species had a half-life of $8 \mathrm{~d}$ in the $10 \mathrm{~mm}$ mesh bags.

The algae placed in bags with 2 different mesh sizes disappeared at significantly different $(p<0.01)$ rates. Algae in the bags with $10 \mathrm{~mm}$ mesh took $39 \mathrm{~d}$ to disappear while the algae in the $2 \mathrm{~mm}$ mesh bags took $55 \mathrm{~d}$. The calculated mean half-life of algae (mixed) in the $10 \mathrm{~mm}$ mesh bags was $8 \mathrm{~d}$ and in the $2 \mathrm{~mm}$ mesh bags $26 \mathrm{~d}$.

The fauna recorded in the mesh bags was similar to that encountered in the samples collected from the surf. Some differences were, however, evident. Macropotasma africanum was encountered only once (only one individual) while the shrimp Palaemon pacificus was abundant (Tables $4 \& 5$ ) in the mesh bags but almost absent in the surf samples (Table 2). Amphipods were responsible for $95 \%$ of the total faunal numbers in the $10 \mathrm{~mm}$ mesh bags and for $98 \%$ in the $2 \mathrm{~mm}$ mesh bags. These percentages are much lower in terms of biomass, i.e. $44 \%$ in the case of the $10 \mathrm{~mm}$ meshed 
Table 2. Number of animals (excluding fish) in samples collected in the surf (numbers/500 $\mathrm{g}$ dry algae)

\begin{tabular}{|c|c|c|c|c|c|}
\hline Animals & $\begin{array}{c}24 \mathrm{Feb} \\
\text { Mean }(\mathrm{n}=4)\end{array}$ & $\begin{array}{c}26 \text { Mar } \\
\text { Mean }(n=8)\end{array}$ & $\begin{array}{c}27 \text { Mar } \\
\text { Mean }(\mathrm{n}=8)\end{array}$ & $\begin{array}{c}28 \mathrm{Mar} \\
\text { Mean }(n=4)\end{array}$ & $\begin{array}{c}19 \mathrm{Apr} \\
\text { Mean }(\mathrm{n}=4)\end{array}$ \\
\hline \multicolumn{6}{|l|}{ AMPHIPODA } \\
\hline Paramoera capensis & 36 & 401 & 2644 & & \\
\hline Elasmopus pectenicrus & 3 & 88 & 346 & & \\
\hline Cyroidea ornata & & 15 & 31 & & \\
\hline Lepidepecreum clypeatum & & 4 & & & \\
\hline \multicolumn{6}{|l|}{ ISOPODA } \\
\hline Cymodocella sublevis & 2 & & 17 & & \\
\hline Synidotea hirtipes & & & 5 & & \\
\hline \multicolumn{6}{|l|}{ MYSIDACEA } \\
\hline Gastrosaccus psammodytes & 12 & & 3 & & \\
\hline \multicolumn{6}{|l|}{ DECAPODA : MACRURA } \\
\hline Palaemon pacificus & & & $<1$ & & \\
\hline Macropotasma africanum & 31 & 1.325 & 10 & 4 & 46 \\
\hline \multicolumn{6}{|l|}{ DECAPODA : BRACHYURA } \\
\hline Dehaanius dentatus & 1 & & 11 & & \\
\hline Leucisca squalina & 1 & 2 & 3 & & \\
\hline Parapilumnus pisifer & & 2 & & & \\
\hline \multicolumn{6}{|l|}{ PYCNOGONIDA } \\
\hline Queubus jamesanus & 1 & & & & \\
\hline POLYCHAETA & 1 & & 12 & & \\
\hline Platynereis dumerilii & 1 & & 5 & & \\
\hline Syllis sp. & & & 3 & & \\
\hline \multicolumn{6}{|l|}{ MOLLUSCA } \\
\hline Tricolia kochii & 7 & 59 & 22 & & \\
\hline Turbo sarmaticus & & & 3 & & \\
\hline Aplysia parvula & 1 & & & & \\
\hline Fissurella mutabilis & 1 & 2 & & & \\
\hline Dinoplax gigas & 1 & 2 & & & \\
\hline Natica tecta & & & 1 & & \\
\hline Perna perna & 9 & 39 & 63 & & \\
\hline Harmenia alfredensis & 1 & & & & \\
\hline Arca obliquata & & & $>1$ & & \\
\hline Unid. gastropod & 1 & & 3 & & \\
\hline \multicolumn{6}{|l|}{ ECHINODERMATA } \\
\hline : OPHIUROIDEA & 1 & 3 & 6 & & \\
\hline : ECHINOIDEA & & & $>1$ & & \\
\hline Parechinus angulosus & & 7 & 7 & & \\
\hline Tripneustes gratilla & 3 & 15 & 8 & & \\
\hline
\end{tabular}

bags and $40 \%$ in the case of the $2 \mathrm{~mm}$ meshed ones. The other most important contributors to the biomass were molluscs, making up $20 \%$ of the total biomass in the $10 \mathrm{~mm}$ mesh bags and $50 \%$ of that of the $2 \mathrm{~mm}$ mesh bags. Summaries of the abundance and biomass data are presented in Table 6.

Analysis of variance of regression coefficients shows a significant difference $(p<0.01)$ between the faunal biomass values of $10 \mathrm{~mm}$ mesh bags and those with $2 \mathrm{~mm}$ mesh. There were significant differences between the 2 replicates of each of the mesh sizes $(p=0.76$ for the $10 \mathrm{~mm}$ mesh and 0.81 for the $2 \mathrm{~mm}$ mesh). Peak epifaunal biomass values were reached between the 9th and the 19th days (Fig. 5), with the highest peaks in the smaller mesh size bags suggesting that this keeps out predators on the epifauna most effectively.

Extremely high epifaunal biomass values per gram dry algae were noted for the last sample date. Filamentous epiphytes had established themselves on the mesh. After most of the macrophytes had gone there were probably enough filamentous epiphytes on the bag surfaces to sustain life for some time. A large proportion of the fauna thus remained in the mesh bags (Fig. 6) even though there were very little of the macrophytes remaining. 
Table 3. Mean abundance and biomass of animals on algae collected in the surf (numbers $/ 500 \mathrm{~g}$ dry algae)

\begin{tabular}{|c|c|c|c|c|c|}
\hline Taxon & & & $24 \operatorname{Mar}(n=4)$ & $26 \operatorname{Mar}(n=8)$ & $27 \operatorname{Mar}(\mathrm{n}=8)$ \\
\hline AMPHIPODA & $\begin{array}{l}\text { Abundance } \\
\text { Biomass }\end{array}$ & $\begin{array}{l}\mathrm{N} \\
\% \\
\mathrm{~B}(\mathrm{~g}) \\
\%\end{array}$ & $\begin{array}{l}38 \\
19.01 \\
0.007 \\
0.15\end{array}$ & $\begin{array}{l}508 \\
55.94 \\
0.040 \\
3.26\end{array}$ & $\begin{array}{c}3021 \\
88.81 \\
0.189 \\
32.26\end{array}$ \\
\hline ISOPODA & $\begin{array}{l}\text { Abundance } \\
\text { Biomass }\end{array}$ & $\begin{array}{l}\mathrm{N} \\
\% \\
\mathrm{~B}(\mathrm{~g}) \\
\%\end{array}$ & $\begin{array}{l}2 \\
0.77\end{array}$ & & $\begin{array}{l}22 \\
1.58 \\
0.014 \\
2.72\end{array}$ \\
\hline DECAPODA & $\begin{array}{l}\text { Abundance } \\
\text { Biomass }\end{array}$ & $\begin{array}{l}\mathrm{N} \\
\% \\
\mathrm{~B}(\mathrm{~g}) \\
\%\end{array}$ & $\begin{array}{l}44 \\
60.95 \\
0.167 \\
60.20\end{array}$ & $\begin{array}{l}1329 \\
27.23 \\
53.384 \\
71.75\end{array}$ & $\begin{array}{l}27 \\
0.66 \\
0.072 \\
9.00\end{array}$ \\
\hline POLYCHAETA & $\begin{array}{l}\text { Abundance } \\
\text { Biomass }\end{array}$ & $\begin{array}{l}\mathrm{N} \\
\% \\
\mathrm{~B}(\mathrm{~g}) \\
\%\end{array}$ & $\begin{array}{l}2 \\
2.01 \\
0.007 \\
2.78\end{array}$ & & $\begin{array}{l}20 \\
0.54 \\
0.005 \\
0.27\end{array}$ \\
\hline MOLLUSCA & $\begin{array}{l}\text { Abundance } \\
\text { Biomass }\end{array}$ & $\begin{array}{l}\mathrm{N} \\
\% \\
\mathrm{~B}(\mathrm{~g}) \\
\%\end{array}$ & $\begin{array}{l}19 \\
12.88 \\
18.656 \\
29.48\end{array}$ & $\begin{array}{c}101 \\
13.24 \\
0.336 \\
17.27\end{array}$ & $\begin{array}{l}91 \\
7.50 \\
0.376 \\
39.01\end{array}$ \\
\hline ECHINODERMATA & $\begin{array}{l}\text { Abundance } \\
\text { Biomass }\end{array}$ & $\begin{array}{l}\mathrm{N} \\
\% \\
\mathrm{~B}(\mathrm{~g}) \\
\%\end{array}$ & $\begin{array}{l}3 \\
4.39 \\
0.025 \\
7.38\end{array}$ & $\begin{array}{l}25 \\
3.59 \\
0.157 \\
7.44\end{array}$ & $\begin{array}{l}21 \\
0.92 \\
0.185 \\
16.73\end{array}$ \\
\hline Total & & $B(g)$ & 18.862 & 53.917 & 0.840 \\
\hline
\end{tabular}

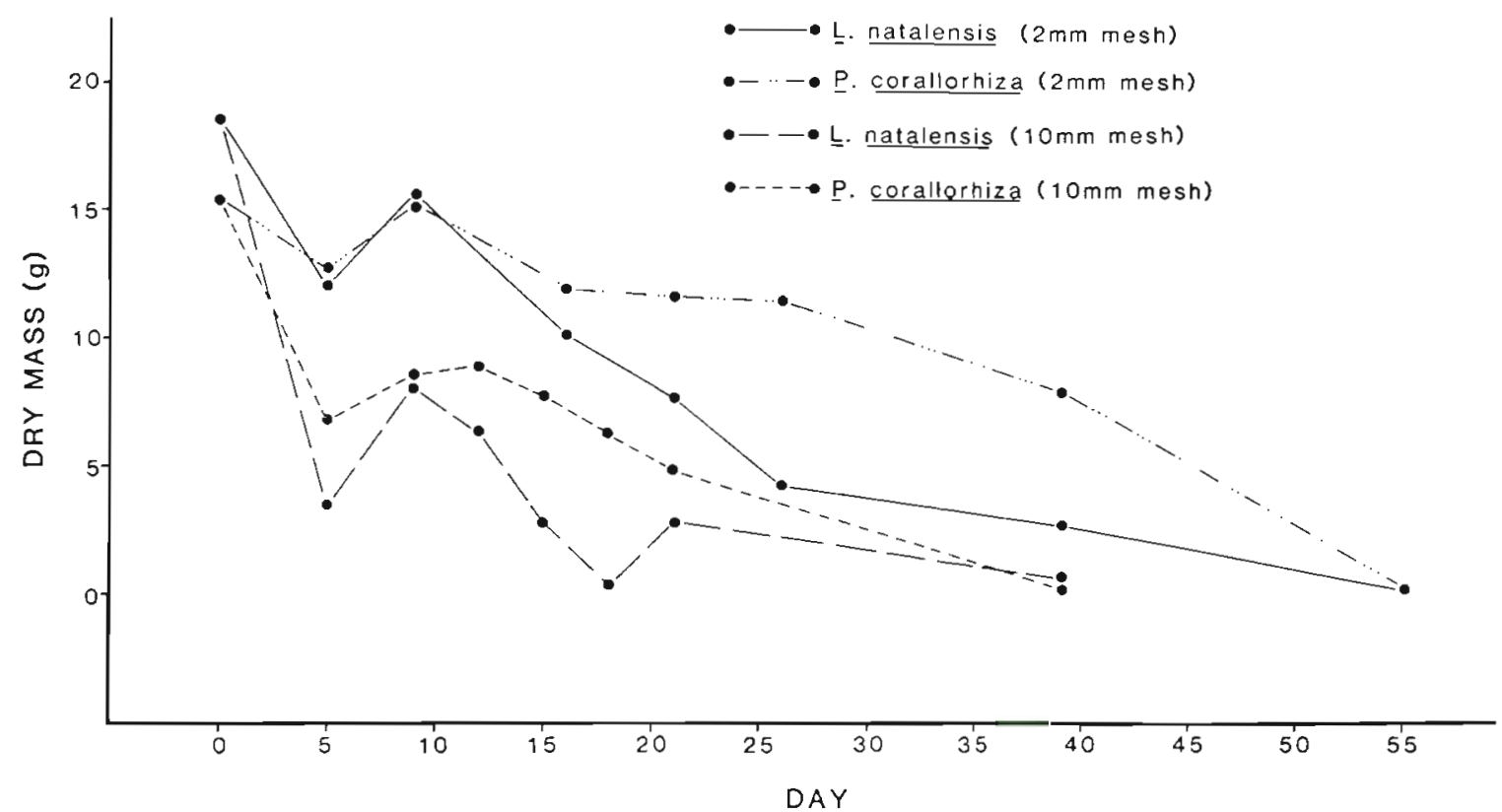

Fig. 4. Laurencia natalensis and Plocamium corallorhiza. Disappearance rates of 2 species of algae in mesh bags 
Table 4. Numbers of animals in bags with 10 mm mesh. ([Bag $1+2$ Bag 2]/2)

\begin{tabular}{|c|c|c|c|c|c|c|c|}
\hline \multirow[t]{2}{*}{ Animais } & \multicolumn{7}{|c|}{ Day } \\
\hline & 5 & 9 & 12 & 15 & 18 & 21 & 39 \\
\hline \multicolumn{8}{|l|}{ AMPHIPODA } \\
\hline Paramoera capensis & 556 & 2106 & 1995 & 1607 & 873 & 2181 & 55 \\
\hline Elasmopus pectenicrus & 34 & 124 & 50 & 44 & 18 & 46 & 12 \\
\hline Cyroidea ornata & 3 & 33 & 12 & 9 & 21 & 36 & 9 \\
\hline Lepidepecreum clypeatum & & & & & 9 & & \\
\hline Ceradocus rubromaculatus & 1 & 1 & & & & & \\
\hline ISOPODA & 5 & 8 & 5 & 7 & & & \\
\hline Cymodocella sublevis & 4 & 15 & 8 & 17 & 16 & 14 & 4 \\
\hline Synidotea hirtipes & & 1 & 1 & 4 & 1 & 4 & 7 \\
\hline Cirolana cranchii & & 1 & 1 & 1 & 3 & 3 & 1 \\
\hline Pansocladus perforatus & & & & & 2 & & \\
\hline \multicolumn{8}{|l|}{ DECAPODA : MACRURA } \\
\hline Palaemon pacificus & 5 & 5 & 77 & 5 & 3 & 3 & \\
\hline \multicolumn{8}{|l|}{ DECAPODA : BRACHYURA } \\
\hline Ovalipes punctatus & & 1 & 1 & 1 & & & \\
\hline Dehaanius dentatus & & & & 1 & & & \\
\hline Leucisca squalina & & 1 & & & & & 2 \\
\hline Plagusia chabrus & & & & 1 & & & \\
\hline POLYCHAETA & 1 & 1 & 1 & 1 & & & \\
\hline Platynereis dumerilii & & & & 1 & 2 & 1 & 2 \\
\hline Syllis sp. & & & & 1 & & & \\
\hline \multicolumn{8}{|l|}{ MOLLUSCA } \\
\hline Tricolia kochii & 1 & 2 & 1 & & & & \\
\hline Turbo sarmaticus & 1 & & 1 & & & & \\
\hline Cerithium pingue & & & 2 & & & & \\
\hline \multicolumn{8}{|l|}{ Natica tecta } \\
\hline Unid. gastropod & & & 1 & 1 & 1 & & \\
\hline \multicolumn{8}{|l|}{ ECHINODERMATA } \\
\hline : OPHIUROIDEA & & 2 & 3 & 2 & 1 & 1 & \\
\hline : ECHINOIDEA & & 1 & & & & & \\
\hline Parechinus angulosus & & 1 & 1 & & 1 & & \\
\hline Tripneustes gratilla & & & & & & 1 & \\
\hline \multicolumn{8}{|l|}{ PISCES } \\
\hline Blennius fascigula & & & & & 1 & & \\
\hline
\end{tabular}

\section{DISCUSSION}

Macrophytes observed in the surf at King's Beach are torn from intertidal rocky shores and from offshore reefs by storms and heavy wave action. They can thus originate from sites quite close to the beach or from reefs and rocky shores as far as $10 \mathrm{~km}$ away. The variable origin of these algae and the great variability of the wind may account for the lack of correlation between wind and algal abundance even though windgenerated local storms are responsible for tearing the algae from the rocks.

Once in the surf at King's Beach the algae move rapidly along shore in a northerly direction, carried by longshore drift which is northwards in this area (CSIR 1970). Whilst sampling, patches of algae in the surf were observed to move up to $50 \mathrm{~m}$ in less than $15 \mathrm{~min}$. No algae were ever washed out on the beach.
Plant accumulations in the surf, unlike wrack deposits on intertidal beaches, are still actively photosynthetic. Tagged kelp plants released $3 \mathrm{~km}$ offshore by Robertson \& Hansen (1982), still had a P/R ratio equal to that of actively growing plants, even though they had been drifting for $8 \mathrm{wk}$. Algae adrift in the surf zone may, however, be physically broken up into smaller pieces. The surf bag experiment showed that fragmentation occurred. Fragmentation of $50 \%$ of the original algal mass to pieces less than $10 \mathrm{~mm}$ and $2 \mathrm{~mm}$ occurred in 8 and $26 \mathrm{~d}$ respectively. It is not known, however, to what extent enclosure in the bags affected the fragmentation rates.

Robertson \& Hansen (1982) found that freshly harvested Ecklonia radiata plants released in the surf had lost $50 \%$ of their original mass after $16 \mathrm{~d}$ and were reduced to $10 \%$ original mass after $24 \mathrm{~d}$. Dead kelp in wrack banks on the other hand declined to $50 \%$ of 
Table 5. Numbers of animals in bags with $2 \mathrm{~mm}$ mesh. $\{[\mathrm{Bag} 1+\mathrm{Bag} 2] / 2\}$

\begin{tabular}{|c|c|c|c|c|c|c|c|}
\hline \multirow[t]{2}{*}{ Animals } & \multicolumn{7}{|c|}{ Day } \\
\hline & 5 & 9 & 16 & 21 & 26 & 39 & 55 \\
\hline AMPHIPODA & 2127 & 2640 & 6541 & 7391 & 5755 & 1457 & 732 \\
\hline Paramoera capensis & 91 & 141 & 135 & 141 & 82 & 78 & 22 \\
\hline Elasmopus pectenicrus & 29 & 24 & 24 & 18 & 12 & 42 & 6 \\
\hline Cyroidea ornata & 9 & 9 & & 12 & & 6 & \\
\hline \multicolumn{8}{|l|}{ ISOPODA } \\
\hline Cymodocella sublevis & 20 & 6 & 18 & 41 & 25 & 8 & 3 \\
\hline Synidotea hirtipes & & & 15 & 2 & 1 & 1 & \\
\hline Cirolana cranchii & & 1 & 3 & 2 & 2 & & \\
\hline Exosphaeroma krausii & & 1 & & & & & \\
\hline \multicolumn{8}{|l|}{ DECAPODA : MACRURA } \\
\hline Palaemon pacificus & 1 & 1 & 2 & 2 & & 1 & 3 \\
\hline Macropetasma africanum & & & & & & 1 & \\
\hline \multicolumn{8}{|l|}{ DECAPODA : BRACHYURA } \\
\hline Ovalipes punctatus & & & & & & 1 & \\
\hline Dehaanius dentatus & & 2 & & & 1 & & \\
\hline Plagusia chabrus & & & & & & & 1 \\
\hline POLYCHAETA & 1 & 1 & 1 & 1 & 1 & & \\
\hline Platynereis dumerilij & & & 1 & 1 & 1 & 1 & 4 \\
\hline Nereis sp. & & & & & & & 1 \\
\hline Syllis sp. & & & & 1 & 1 & & \\
\hline \multicolumn{8}{|l|}{ MOLLUSCA } \\
\hline Tricolia kochii & 1 & & 4 & & & 1 & \\
\hline Turitella carinifera & 1 & & & & & & \\
\hline Turbo sarmaticus & & 1 & 2 & 2 & 2 & 1 & \\
\hline Turbo cidaris & & 1 & 1 & & & & \\
\hline Cerithium pingue & 1 & 3 & 1 & 1 & & & \\
\hline Aplysia parvula & & & & & & 12 & \\
\hline Unid. gastropod & 1 & & 1 & 1 & 1 & & \\
\hline \multicolumn{8}{|l|}{ ECHINODERMATA } \\
\hline : OPHIUROIDEA & 1 & 2 & 5 & 7 & 10 & 6 & \\
\hline \multicolumn{8}{|l|}{ ECHINOIDEA } \\
\hline Parechinus angulosus & & & 1 & 1 & 1 & 2 & \\
\hline Tripneustes gratilla & & & 2 & & & 2 & \\
\hline : HOLOTHUROIDEA & 1 & 1 & 2 & & & 1 & \\
\hline
\end{tabular}

their initial weight within $2 \mathrm{~d}$ and to $20 \%$ by $14 \mathrm{~d}$ (Griffiths \& Stenton-Dozey 1981). This rapid breakdown of the algae on sandy beaches is mainly attributed to its consumption by amphipods and dipteran larvae (Griffiths \& Stenton-Dozey 1981), and on rocky shores by the isopod Ligia dilatata (Koop \& Field 1981).

Taking into account the relatively slow breakdown of macrophytes in the surf zone and their transient nature there, it can be concluded that these free-floating algae contribute little energy to the beach/surf zone ecosystem at King's Beach. This is contrary to findings on western Australian beaches where it was estimated that a quarter of the total coastal primary production $\left(2.9 \times 10^{5} \mathrm{~g} \mathrm{C} \mathrm{m}^{-1}\right.$ of coast $)$ passes through the surf zone and sandy beaches as dislodged algae (Robertson \& Hansen 1982).

Large clumps of drift algae are a common feature of a number of coastal communities and several macro- invertebrates and fish species have been reported to be intimately associated with them (Lenanton et al. 1982). A comparison of relative abundance of juvenile fishes in an estuary and the nearby inshore marine habitat has shown that the juveniles of a number of fish species use portions of the open coast of south-western Australia as an alternative to estuarine nursery areas (Lenanton [in press] cited in Lenanton et al. 1982).

These detached macrophyte accumulations provide food and shelter for fishes, as amphipods, a major prey item for juvenile fishes, are restricted to detached plants and the fish are all shallow water species (Lenanton 1977). These large accumulations of detached seaweeds provide important feeding sites for the fishes in western Australia (Lenanton et al, 1982) and also provide protection from other predators, like larger fish and birds.

Lasiak (1981) showed the importance of the surf zone 
Table 6. Percent abundance (N) and biomass $(B)$ of animals in mesh bags

\begin{tabular}{|c|c|c|c|c|c|c|c|c|c|c|c|c|c|c|c|c|}
\hline & \multicolumn{2}{|c|}{$\begin{array}{l}\text { AMPHI- } \\
\text { PODA }\end{array}$} & \multicolumn{2}{|c|}{ ISOPODA } & \multicolumn{2}{|c|}{ DECAPODA } & \multicolumn{2}{|c|}{$\begin{array}{l}\text { POLY- } \\
\text { CHAETA }\end{array}$} & \multicolumn{2}{|c|}{ MOLLUSCA } & \multicolumn{2}{|c|}{$\begin{array}{l}\text { ECHINO- } \\
\text { DERMATA }\end{array}$} & \multicolumn{2}{|c|}{ PISCES } & \multirow{2}{*}{$\begin{array}{c}\text { Total } \\
\text { num- } \\
\text { bers }\end{array}$} & \multirow{2}{*}{$\begin{array}{l}\text { Total } \\
\text { bio- } \\
\text { mass }\end{array}$} \\
\hline & $\mathrm{N}$ & B & $N$ & B & $\mathrm{N}$ & B & $\mathrm{N}$ & B & $N$ & B & $N$ & B & $\mathrm{N}$ & B & & \\
\hline \multicolumn{17}{|c|}{10 mm mesh size } \\
\hline \multicolumn{17}{|c|}{ Day } \\
\hline 5 & 97.25 & 27.45 & 1.70 & 0.65 & 0.72 & 2.10 & 0.05 & 0.10 & 0.30 & 69.70 & & & & & 608 & 0.391 \\
\hline 9 & 98.45 & 68.15 & 1.05 & 1.05 & 0.25 & 23.65 & 0.04 & 0.02 & 0.05 & 6.35 & 0.12 & 0.62 & & & 2298 & 0.326 \\
\hline 12 & 95.05 & 42.35 & 0.65 & 1.00 & 3.90 & 9.15 & 0.02 & 0.01 & 0.25 & 45.95 & 0.16 & 1.55 & & & 2157 & 1.145 \\
\hline 15 & 97.75 & 29.70 & 1.50 & 2.80 & 0.43 & 52.95 & 0.18 & 0.16 & 0.05 & 14.20 & 0.10 & 0.15 & & & 1699 & 0.545 \\
\hline 18 & 97.05 & 51.60 & 2.30 & 6.90 & 0.30 & 1.40 & 0.20 & 16.90 & 0.10 & 0.20 & 0.10 & 0.30 & 0.05 & 22.60 & 948 & 0.409 \\
\hline 21 & 98.20 & 76.10 & 1.70 & 22.65 & 0.05 & 0.85 & 0.01 & 0.15 & & & 0.03 & 0.25 & & & 2286 & 0.204 \\
\hline \multirow[t]{2}{*}{39} & 82.45 & 9.90 & 13.10 & 47.05 & 2.10 & 42.35 & 2.30 & 0.70 & & & & & & & 90 & 0.095 \\
\hline & 95.17 & 43.61 & 3.14 & 11.73 & 1.11 & 18.92 & 0.40 & 2.58 & 0.11 & 19.49 & 0.07 & 0.41 & 0.01 & 3.23 & & \\
\hline \multicolumn{17}{|c|}{$2 \mathrm{~mm}$ mesh size } \\
\hline 5 & 98.95 & 52.55 & 0.85 & 0.55 & 0.02 & 0.10 & 0.02 & 0.01 & 0.14 & 46.70 & 0.07 & 0.10 & & & 2280 & 0.501 \\
\hline 9 & 99.35 & 15.00 & 0.25 & 0.30 & 0.10 & 4.45 & 0.05 & 0.01 & 0.15 & 80.10 & 0.12 & 0.15 & & & 2831 & 1.564 \\
\hline 16 & 99.20 & 22.70 & 0.55 & 1.00 & 0.02 & 0.10 & 0.02 & 0.10 & 0.10 & 75.70 & 0.10 & 0.35 & & & 6753 & 1.627 \\
\hline 21 & 99.15 & 45.35 & 0.60 & 2.45 & 0.03 & 0.25 & 0.03 & 1.85 & 0.05 & 47.85 & 0.06 & 2.25 & & & 7620 & 0.885 \\
\hline 26 & 99.30 & 34.50 & 0.45 & 1.75 & 0.01 & 0.02 & 0.04 & 0.03 & 0.05 & 62.15 & 0.12 & 1.95 & & & 5891 & 0.747 \\
\hline 39 & 89.35 & 15.90 & 3.75 & 2.50 & 1.22 & 12.55 & 0.62 & 9.90 & 2.15 & 35.10 & 3.15 & 24.00 & & & 1617 & 0.756 \\
\hline \multirow[t]{2}{*}{55} & 98.80 & 92.85 & 0.30 & 2.10 & 0.40 & 4.65 & 0.45 & 0.18 & & & & & & & 770 & 0.072 \\
\hline & 97.73 & 39.84 & 0.96 & 1.52 & 0.26 & 3.16 & 0.17 & 1.72 & 0.38 & 49.66 & 0.52 & 4.11 & & & & \\
\hline
\end{tabular}

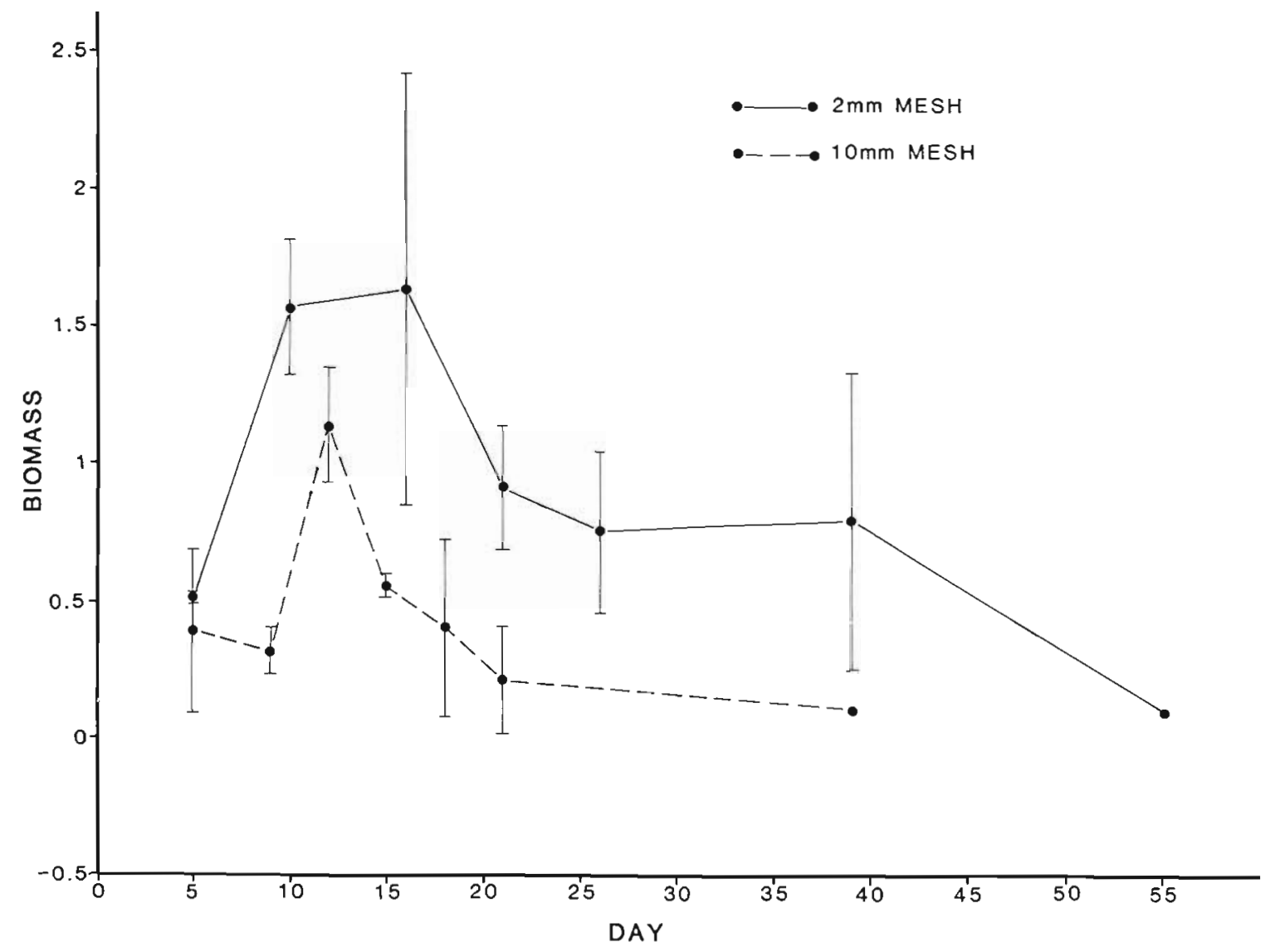

Fig. 5. Total faunal biomass values in the mesh bags versus time. (Vertical bars indicate range of 2 replicates) 


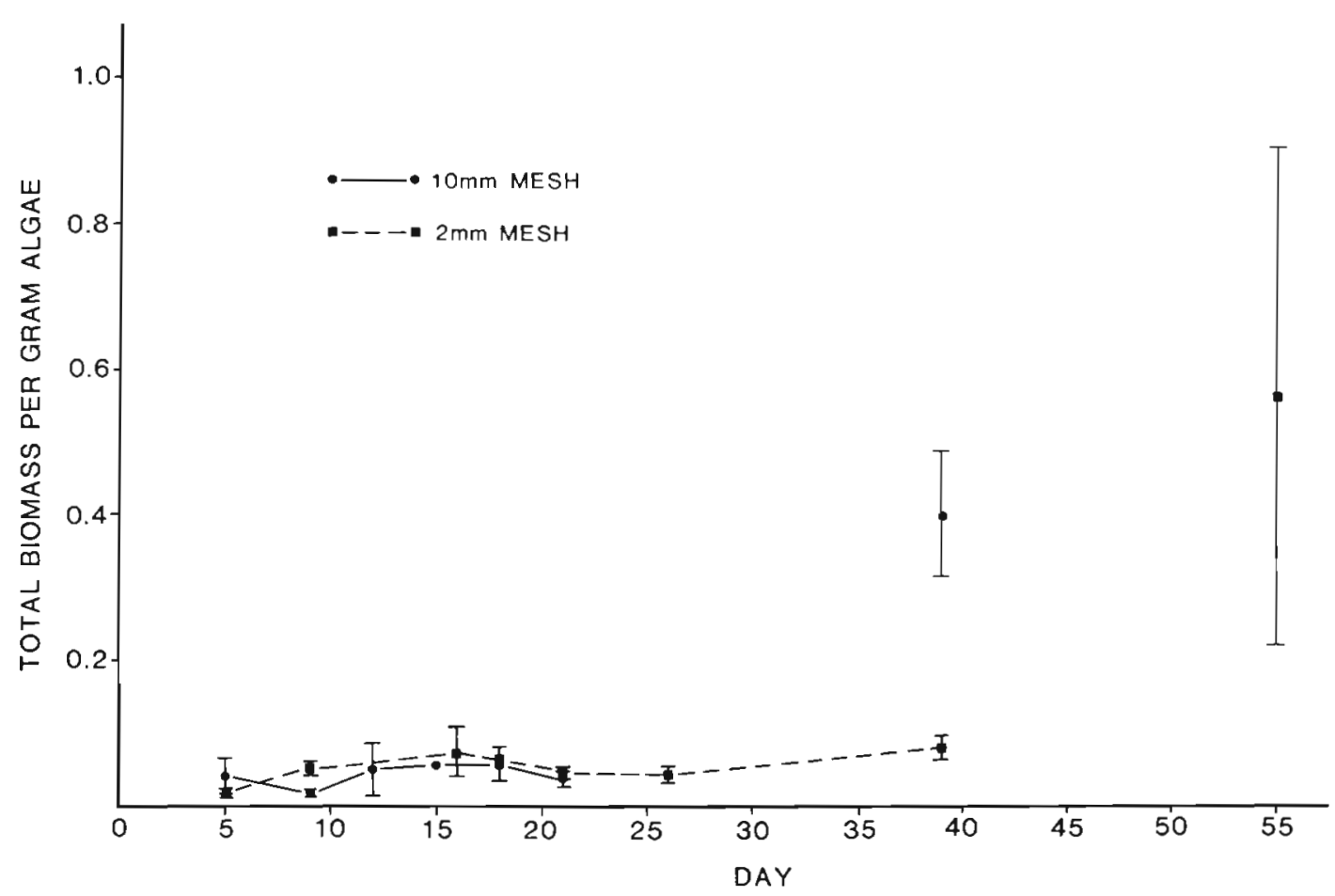

Fig. 6. Total faunal biomass per g algae versus time. (Vertical bars indicate range)

at King's Beach as a nursery area for juvenile ichthyofauna. In terms of numbers, Lasiak (1981) found 5 dominant species accounted for $90.2 \%$ of the juvenile fishes caught. She found that large numbers of fish $<5 \mathrm{~cm}$ were caught throughout the year at King's Beach, which suggests that this environment is important for small juveniles (Lasiak 1982).

No correlation was found between the abundance of juvenile fish and the occurrence of algae at King's Beach. However, this does not mean that the juvenile fish would not use the algae as shelter from predators when it is present in the surf. They might also feed on epifauna associated with the algae and even on the algae itself. The fact that animal species found in the detached macrophytes in the surf at King's Beach were present in fish stomachs analysed by Lasiak (1983a) supports this statement. Some algae was also present in certain fish stomachs (Lasiak 1983a). The epifauna and algae could, however, have been obtained from nearby reefs (Lasiak 1983b).

The suitability of King's Beach as a nursery area (Lasiak 1981) is probably a consequence of an abundant food supply in the form of zooplankton, and some protection from predators afforded by turbid water in the surf zone may be significant.

Kulcyzcki et al. (1981) found gobies and pipefish associated with drift algae in Florida and suggested that the drift algae provide a refuge from predation which increases in effectiveness with increased algal biomass. Heck (1979) found 7 times the invertebrate abundance in a temperate seagrass community with high algal biomass compared to a tropical seagrass community with little or no drift algae and partially attributed this difference to the extra protection from predation provided by the algal clumps. This was confirmed by Mukai (1971) who also found a positive correlation between numbers of animals and the standing crop of floating algae. Nelson (1979) similarly found that the density of eelgrass had a significant effect on predation rates of the grass shrimp Palaemonetes vulgaris on amphipods in the algae. The effect of predation on seasonal abundance and diversity of amphipods in eelgrass, however, appeared to be directly affected by the relative susceptibility to predation of amphipods of different types, i.e. infaunal, epifaunal tube builders or epifaunal free-living forms (Nelson 1979).

Amphipods found in the drift algae at King's Beach were mainly free-living. Paramoera capensis, one of the most abundant amphipods in the algae on rocky shores in this area (Branch \& Branch 1981), made up $86 \%$ of the epifauna on the detached macrophytes. These amphipods probably feed on the algae or on epiphytes associated with the algae, as observed for the amphipod Allorchestes compressa in Australia (Robertson \& Lucas 1983).

Only 3 invertebrate species normally resident in the sandy beach surf zone were encountered in the bags (Table 5), i.e. the prawn Macropetasma africanum, the mysid shrimp Gastrosaccus africanum and the 3-spotted swimming crab Ovalipes punctatus. It thus seems 
that the fauna observed in the drift algae at King's Beach mostly accompany the algae from its origin and that little or no subsequent colonization takes place. The greater abundance and persistence of the epifauna in the bags of finer mesh suggest that they excluded predators (fishes) that could enter the coarse meshed bags. The resident surf fauna probably only utilize the algae as a source of food for the short time it takes to move through the surf zone at King's Beach.

It seems that surf zone macrophytes are a transient feature at King's Beach and their origin and occurrence in relation to sea conditions and winds are uncertain. While in the surf zone, these macrophytes are living and actively photosynthesizing, thus breaking down very slowly. According to our findings they are not important in beach energetics in this area and do not form an important nursery area for juvenile fishes at King's Beach. The fauna associated with the algae is mostly derived from their sites of origin. In contrast to previous studies elsewhere, King's Beach thus constitutes one case where macrophyte input is not of major importance to beach/surf zone energetics or ecology. This implies that macrophytes are important only in surf zones where they occur in large quantities and have long residence times.

Acknowledgements. We thank Dr Ted Donn and Mr B. Tomalin for their help in identification of the animals, and Mrs W. du Preez for her help in identification of the algae. We thank Mrs Debbie van der Merwe, Miss J. Goosen, Miss S. van der Merwe, Miss L. van der Merwe and Mr A. Cockcroft for their aid and $\mathrm{Mr} \mathrm{H}$. du Preez for permission to use seining information. We are also extremely grateful to Dr D. Venter for his help in analysing the data. Financial support came from CSIR and Department of Environment Affairs, South Africa.

\section{LITERATURE CITED}

Branch, G., Branch, M. (1981). The living shores of Southern Africa. C. Struik, Cape Town

Cowper, S. W. (1978). The drift algae communities of seagrass beds in Redfish Bay, Texas. Contr. mar. Sci. 21: 125-132

CSIR (1970). Algoa Bay coastal erosion investigation. Part 1. Main report. National Mechanical Engineering Research Institute, CSIR, Stellenbosch

Eiseman, N. J., Benz, M. C. (1975). Marine algae of the Indian River. I. Species of the algal drift community collected from April 1974 to April 1975. Technical Report No. 1, Harbor Branch Foundation, Inc., Fort Pierce, Florida

Gore, R. H., Gallaher, E. E., Scotto, L. E., Wilson, K. A. (1981). Studies on decapod Crustacea from the Indian River region of Florida. Estuar. coast. Shelf Sci. 12: 485-508

Griffiths, C. L., Stenton-Dozey, J. (1981). The fauna and rate of degradation of stranded kelp. Estuar. coast. Shelf Sci. 12: 645-653

Heck, K. L., Jr. (1979). Some determinants of the composition and abundance of total macroinvertebrate species in tropical and temperate turtlegrass (Thalassia testudinum) meadows. Biogeogr. 6: 183-200

Heck, K. L., Jr., Thoman, T. A. (1981). Experiments on predator-prey interactions in vegetated aquatic habitats. J. exp. mar. Biol. Ecol. 53: 125-134

Hooks, T A., Heck, K. L., Livingston, R. J. (1976). An inshore marine invertebrate community: structure and habitat associations in the northeastern Gulf of Mexico. Bull. mar. Sci. 26: 99-109

Koop, K., Field, J. G. (1981). Energy transformation by the sub-littoral isopod Ligia dilatata. J. exp. mar. Biol. Ecol. 53: 221-233

Kulczycki, G. R., Virnstein, R. W., Nelson, W. G. (1981). The relationship between fish abundance and algal biomass in a seagrass-drift algae community. Estuar. coast. Shelf Sci. 12: $341-347$

Lasiak, T. A. (1981). Nursery grounds of juvenile teleosts: evidence from the surf zone of King's Beach, Port Elizabeth. S. Afr. J. Sci. 77: 388-390

Lasiak, T. A. (1982). Recruitment and growth patterns of juvenile marine teleosts caught at King's Beach, Algoa Bay. S. Afr. J. Zool. 18 (1): 25-30

Lasiak, T. A. (1983a). Aspects of the biology of three benthicfeeding teleosts from King's Beach, Algoa Bay, S. Afr. J. Zool. 19 (1): 51-56

Lasiak, T. A. (1983b). The impact of surf zone communities on faunal assemblages associated with sandy beaches. In: McLachlan, A., Erasmus, T. (ed.) Sandy beaches as ecosystems. Dr. W. Junk, The Hague, p. 501-506

Lasiak, T. A. (1984). Structural aspects of the surf zone fish assemblage at King's Beach, Algoa Bay, South Africa: long-term fluctuations. Estuar. coast. Shelf Sci. 18: 459-483

Lenanton, R. C. J. (1977). Aspects of the ecology of fish and commercial crustaceans of the Blackwood River estuary, Western Australia. Fish. Bull. West. Aust. 19: 1-72

Lenanton, R. C. J., Robertson, A. I., Hansen, J. A. (1982). Nearshore accumulations of detached macrophytes as nursing area for fish. Mar. Ecol. Prog. Ser. 9: 51-57

McLachlan, A. (1977). Studies on the psammolittoral meiofauna of Algoa Bay, South Africa. I. Physical and chemical evaluation of the beaches. Zool. Afr. 12: 15-32

McLachlan, A. (1979). Volumes of sea water filtered by East Cape sandy beaches. S. Afr. J. Sci. 75: 75-79

McLachlan, A. (1980). The definition of sandy beaches in relation to exposure: a simple rating system. S. Afr. J. Sci. 76: $137-138$

Mukai, H. (1971). The phytal animals on the thalli of Sargassum serratifolium in the Sargassum region, with reference to their seasonal fluctuations. Mar. Biol. 8: 170-182

Nelson, W. G. (1979). Experimental studies of selective predation on amphipods: consequences for amphipod distribution and abundance. J. exp. mar. Biol. Ecol. 38: 225-245

Robertson, A. I., Hansen, J. A. (1982). Decomposing seaweed: nuisance or a vital link in coastal food chains? CSIRO Marine Laboratories Report 1979-1981, p. 75-83

Robertson, A. I., Lucas, J. S. (1983). Food choice, feeding rates, and the turnover of macrophyte biomass by a surf zone inhabiting amphipod. J. exp. mar. Biol. Ecol. 72: 99-124

Zobell, C. E. (1971). Drift seaweeds on San Diego county beaches. In: North, W. J. (ed.) The biology of giant kelp beds (Macrocystis) in California. Nova Hedwigia 32 (Suppl.): 269-314 